\title{
The Process Leading to Physician Activism for Sustainable Change
}

\author{
Efraïm Hart $^{1, *}$, Giliam Kuijpers ${ }^{2}$, Glenn Laverack ${ }^{3}$ (D) and Fedde Scheele ${ }^{1,4,5}$ \\ 1 Department of Medical Education, OLVG Hospital, 1091 AC Amsterdam, The Netherlands; f.scheele@olvg.nl \\ 2 Training Institute and Social Enterprise MedGezel, 1381 XZ Weesp, The Netherlands; giliam@medgezel.nl \\ 3 Department of Sociology and Social Research, University of Trento, 38122 Trento, Italy; grlavera@hotmail.com \\ 4 Athena Institute for Transdisciplinary Research, VU University Amsterdam, \\ 1081 HV Amsterdam, The Netherlands \\ 5 Institute for Education and Training, Amsterdam University Medical Centers, Location VUmc, \\ 1105 AZ Amsterdam, The Netherlands \\ * Correspondence: Efraim.Hart@gmail.com
}

Citation: Hart, E.; Kuijpers, G.; Laverack, G.; Scheele, F. The Process Leading to Physician Activism for Sustainable Change. Sustainability 2021, 13, 10003. https://doi.org/ $10.3390 /$ su131810003

Academic Editors: Jacqueline Broerse, Evelien de Hoop and Tjerk Jan Schuitmaker

Received: 29 June 2021

Accepted: 30 August 2021

Published: 7 September 2021

Publisher's Note: MDPI stays neutral with regard to jurisdictional claims in published maps and institutional affiliations.

Copyright: (c) 2021 by the authors. Licensee MDPI, Basel, Switzerland. This article is an open access article distributed under the terms and conditions of the Creative Commons Attribution (CC BY) license (https:/ / creativecommons.org/licenses/by/ $4.0 /)$.

\begin{abstract}
Health systems all over the world are in a process of transition and may even need a paradigm shift for sustainable development. This is where activism may play a role. This study focused on why some physicians become activists and how these physicians have either achieved successes or failed to do so. This study is inspired by grounded theory. Semi-structured, in-depth interviews were conducted to evaluate the experiences of seven purposefully sampled physicianactivists from the Netherlands. Our research suggests that activism originates from an awareness of problems in the area of health inequalities, resulting in moral discomfort combined with a strong drive to speak up against perceived failings, even when personal risks may be involved. Activists that were most successful in achieving political and health changes meandered effectively along the borders of the system, taking care to preserve ties with supporters within that system and, at the same time, taking a relatively isolated position while using strategies to oppose the system. Diverging too much from the system resulted in measures taken by the system to silence them. Successful activism may be regarded as a social and professional skill that may be learned.
\end{abstract}

Keywords: health activism; physician-activists; doctor-activists; health advocacy; sustainable development goals; health inequality; medical education

\section{Introduction}

Health systems all over the world are in a process of transition and may even need a paradigm shift for sustainable development, "development that meets the needs of the present generation without compromising the ability of future generations to meet their own needs" [1], and to comply with the Sustainable Development Goals (SDGs) by 2030 [2-7]; however, systemic transition is a complex process [1,8,9] that has "a long-term timeframe covering a period of one or two generations" [8].

Globally, but also in the Netherlands, there are major and urgent health issues that are related to the SDGs and have been the center of attention in the past few years, such as the affordability of the healthcare system, sexual and reproductive health and rights, patientcentered care, climate effects on health, and the effects of health systems on pollution in general, lifestyle diseases, and the increase in alcohol and tobacco consumption. Since the end of 2019, an additional concern has been the control of the COVID-19 pandemic and how to prevent future pandemics.

To solve these major and often urgent health issues, there is a need for drastic systematic change [10], which makes the long-term timeframe of a transition undesirable.

To effect drastic systematic change, activism may play a role. Activism is the use of direct and noticeable action, "action that goes beyond what is conventional or routine" [11-13], 
to achieve a result or, in this context, to address health inequalities or injustice. While the role of activism in societies and institutions has been described more extensively in social movement and institutional change theory [14], some healthcare ethicists believe that physicians have a responsibility to engage in the political process to advocate policies that improve the health of patients or populations and decrease health inequality [15]. The problem addressed in this article is that, despite this conviction among ethicists, it is difficult to find physicians in today's healthcare system who show activism while addressing these major and urgent health issues.

Historically, health activists and specifically physician-activists have played vital roles in stimulating and effecting change [11], challenging the status quo and the existing power structures, also called 'the system' $[7,16]$. Particularly, the combination of activism and scientific evidence has led to lasting improvements in healthcare [11], from the development of the first vaccines by Edward Jenner and the social and political reform of medicine by Rudolf Virchow [17] to hygiene and sanitary improvements [18], alcohol and tobacco control [11,19], and the prevention of the spread of AIDS [20,21].

The question of whether activism may also play a more important role in healthcare becomes more relevant when we study other industries. Several systems and institutions are developing under the influence of activists, and there is also discussion about the role of activists in these systems [22]. Companies can be held accountable for not meeting stakeholder demands, as stakeholders can take actions (boycotts, strikes, lawsuits, etc.,) to sanction a company in an attempt to change a company's actions. "One motivation for corporations to adopt corporate social performance (CSP) is to satisfy stakeholders beyond those of a corporation's shareholders" [23]. Because companies benefit from a good relationship with their stakeholders, activist stakeholders can have a major influence on the changes in a company.

If we look at the health system, physicians can have great influence as stakeholders, because they play an important role within it.

Activism has much overlap with advocacy $[15,24]$. "As Health Advocates, physicians contribute their expertise and influence as they work with communities or patient populations to determine and understand needs, speak on behalf of them when required, and support the mobilization of resources to effect change and improve health" [25]. Not all the key concepts of health advocacy are equally represented in medical education. For example, in the CanMEDS framework, which defines the roles a physician should master, advocacy for the health of communities or populations is one of the key features of the 'Health Advocate' role [25]. However, according to the CanMEDS tool guide, which trainers use to train future physicians, one of the misconceptions about the Health Advocate role is that "learners may associate advocacy with activism, while the prospect of incorporating such activism into regular, everyday practice may be daunting for clinicians. Many learners identify more readily with working within the system day to day to meet the health needs of a specific patient or community, as a health 'agent'" [25]. By framing activism as daunting for clinicians, physicians all over the world are being discouraged to engage in activism, and this could partially explain the relative lack of educational interventions related to system-level change and policy reform $[6,16,26,27]$. For example, in current health education curricula in the Netherlands, there is no place for skills that are supportive of activism, and, in healthcare practice, it is not easy to detect examples of activists.

Activism has proven its value in bringing about change. We wonder whether the current health system, which is in a process of transition for sustainable development, could benefit from some activism. Therefore, it will be interesting to explore what caused this scarcity of activism among physicians and how those who did become activists thrived, both concerning their achieving of success and in their careers. To gain a better understanding of physician health activism, we aimed to gather the views and experiences of health activists in the Dutch health system.

In a first step to answering this question, we posed the following research questions:

1. Why would a physician engage in health activism? 
2. What are the most prominent features of an effective health activism strategy in the context of the Dutch health system?

3. Could education prepare for skills that are supportive for effective health activism?

\section{Materials and Methods}

\subsection{Study Design}

A qualitative interview study was conducted by collecting data in semi-structured interviews and analyzing these data using thematic analysis, inspired by grounded theory [28].

\subsection{Participants and Recruitment}

The study evaluated the experiences of physician health activists in the Netherlands who were renowned in media. To determine if the participating physicians were health activists, the participants had to focus their actions on changing a societal or health issue using their expertise. The actions of the participants had to be beyond or even against the expectation of their employer or function.

We focused on recruiting information-rich cases through purposeful typical case sampling and used the snowball sampling technique, in which the participants provide referrals or names of other health activists. Potential participants were contacted by the researcher through their websites and social media [29]. We recruited both activists that achieved success by reaching their predetermined goals through activism and those who experienced failures, as a way to identify a common motivation among all activists and to discover which factors might lead to success. We also evaluated personal consequences or (dis)advantages due to activism, to see if these (dis)advantages might be of influence in the process or the motivation to (not) engage in further activism. Informed consent to participate in the study was obtained from all participants. There was no power relationship nor conflict of interest between the researcher and the participants. Member checking was not performed. All participants agreed that results would be shared after publication.

\subsection{Data Collection}

The interviews were conducted through Zoom. A list was compiled with multiple open-ended questions on 6 topics concerning activism: 1. Self-image of activists and differences between them and their colleagues; 2 . Activist's motivation and personality; 3 . Experiences of resistance, support, and consequences; 4 . The role of education; 5 . The activist's relation to the system; 6 . Success factors and goals. Questions were formulated, for example, as follows: 'Were there consequences due to your activism?' and 'How did you achieve your goals?' All interviews were audio recorded and professionally transcribed.

\subsection{Analytical Approach}

The analytic framework used in this study was based on thematic analysis inspired by grounded theory, which is commonly used in qualitative research to identify major themes in textual data. This approach allows themes to emerge directly from the data and prioritizes participants' experiences and perspectives [29]. Preliminary analysis of the interview transcripts involved open coding, with author EH reading the transcripts line by line to identify and develop ideas, themes, and issues from the data, followed by axial coding and a discussion of the analysis with author FS. A coding framework was then developed. The transcripts were coded and analyzed using the software Atlas.TI version 9.0.7.

We used an inductive and deductive coding approach. The analysis procedure consisted of the inductive identification of text fragments (codes) and clustering of codes into categories, alternated with deductive discussions about emerging themes within the team of authors. Differences in the researchers' views on coding and categorizing were discussed until a consensus was reached. The authors further iteratively processed the codes, categories, and emerging themes, verified them during the next interviews, and 
supplemented them with additional interview data. When data saturation became evident and no new relevant data relating to our research questions emerged from interviews [30], we made the final deductive step.

\subsection{Reflexivity}

As team of authors, we have discussed potential bias based on background, interests, values, and life experience. At different moments during our research, we reflected on how this research shaped our perspective of health activism and we discussed preconceptions about health activism and about the areas of activism in which the participants were active. We interviewed all participants with 2 researchers to further separate our personal views from the research [31]. The first author and main researcher is a medical doctor and educational consultant and is involved in local politics. The second author worked as a pediatrician, has a master's degree in change management, and is currently a social entrepreneur. The third author is a visiting professor at the department of sociology and social research in Italy, an honorary professor in health promotion, and a member of the World Health Organization's technical advisory group on behavioral insights and sciences for health. The fourth author is a gynecologist and a professor in Health Systems Innovation and Education, as well as an expert in change management and qualitative research.

\section{Results}

\subsection{Participants}

A total of seven health activists (five female and two male) were asked to participate in the study and gave their informed consent. Of the seven included activists, five were specialists, one was at the end of her specialist training, and one had no further training after medical school. The participants aimed their activism at COVID-19 (two), abortion and gender inequality (two), patient-centered healthcare (one), tobacco and cancer (one) and sustainable health (1). The age of the participants varied from 36 to 65 years, the duration of their experience as a physician varied from 10 to 43 years, and their experience in activism varied from 1 to 22 years.

All the interviews were conducted in Dutch, the language in which all the participants were highly proficient. The interviews varied in length (between 45 and 65 mins). The data was collected in a period of 3 months, from February to April 2021. Data saturation was reached after five interviews. After these interviews, we started analyzing the data We used the last two interviews to verify data saturation.

Participants revealed that their activism was not motivated by one particular moment but based on a process, and that its development had been determined by choices made within several themes (Table 1). In total, six themes were detected, which are presented below in stages of development to either dropping out of activism or empowerment towards an activist role: Awareness, Moral discomfort, Action within the system, Resistance from within the system, Turning into an activist, and Personal (dis)advantages of activism.

Table 1. Development of activism.

\begin{tabular}{ccc}
\hline Development of Health Activism & $\begin{array}{c}\text { Reasons Explaining Why Development } \\
\text { of Health Activism Occurs }\end{array}$ & $\begin{array}{c}\text { Reasons Explaining Why NO } \\
\text { Development of Health Activism Occurs }\end{array}$ \\
\hline Education & $\begin{array}{c}\text { Learning various attributes relevant to } \\
\text { activism } \\
\text { Teaching critical thinking in medical } \\
\text { education }\end{array}$ & $\begin{array}{c}\text { Activism is not part of curriculum } \\
\text { Activism regarded as daunting by } \\
\text { professionals }\end{array}$ \\
\hline Awareness & Raising awareness of social injustice and \\
health inequalities & $\begin{array}{c}\text { Either you do not see it or you do not want } \\
\text { to, and you mitigate the suffering of the } \\
\text { disadvantaged }\end{array}$ \\
\hline
\end{tabular}


Table 1. Cont.

\begin{tabular}{|c|c|c|}
\hline Development of Health Activism & $\begin{array}{l}\text { Reasons Explaining Why Development } \\
\text { of Health Activism Occurs }\end{array}$ & $\begin{array}{c}\text { Reasons Explaining Why NO } \\
\text { Development of Health Activism Occurs }\end{array}$ \\
\hline Moral discomfort & $\begin{array}{l}\text { Focus on what values underlie medicine } \\
\text { Conversations about norms and values }\end{array}$ & $\begin{array}{c}\text { You better stay within your circle of } \\
\text { influence } \\
\text { Just accept the status quo and be } \\
\text { a physician }\end{array}$ \\
\hline Action within the system & $\begin{array}{l}\text { Safe working environment to initiate and } \\
\text { discuss different ideas and opinions }\end{array}$ & $\begin{array}{l}\text { Speaking up in a silent group is } \\
\text { challenging, as finding ways to induce } \\
\text { system improvement }\end{array}$ \\
\hline Resistance & $\begin{array}{c}\text { Actively give a voice to countervailing } \\
\text { power or people with less power } \\
\text { within groups }\end{array}$ & $\begin{array}{l}\text { Now the system acts critical upon you } \\
\text { You experience personal risks }\end{array}$ \\
\hline Activism & $\begin{array}{l}\text { Knowing how far you want to go to } \\
\text { achieve your goal }\end{array}$ & $\begin{array}{l}\text { It is lonely in the spotlights } \\
\text { The system is defending itself, risk } \\
\text { is tangible }\end{array}$ \\
\hline Successful activism & $\begin{array}{l}\text { Learn new skills and stay open for } \\
\text { feedback and improvement }\end{array}$ & $\begin{array}{c}\text { You have lost contact with your peers } \\
\text { You are being expelled }\end{array}$ \\
\hline
\end{tabular}

Development of health activism. In every step leading to health activism, there are reasons for physicians to stop further development. Based on the conversations, we suggest potential improvements in which systems could help the development of health activism. During our study, we learned most of negative experiences in the development of health activism. In the last column, we summarize the stagnating and negative experiences in the development of health activism.

\subsection{Awareness}

The participants reported to have been interested from an early age in finding ways to potentially change or improve the world. The participants are critical by nature, dare to ask questions, and also attach great value to finding a purpose in life: "I see myself as a part of something bigger, and that bigger entity can become better"-participant 7.

The first step in the participants' motivation to become involved in actively promoting a specific goal was the awareness of a specific problem. For the participants, the problems were mainly in the area of social, economic, and gender inequality, which resulted in a focus on health inequalities between groups. One of the participants remarked that these inequalities are not visible to everyone: "If you don't know about it, you can't see it" -participant 5. On the other hand, participants assumed that some people deliberately ignored these problems.

Several participants mentioned that their awareness was triggered by fellowships in developing countries, but for one participant, the moment of awareness resulted from an experience in a high-income country: "In Sweden, everything was much better organized, even parental leave for fathers" - participant 2 . One of the participants indicated that experience abroad may obviously contribute to awareness, but that it does not necessarily turn a physician into an activist: "I know several people in the WHO and they saw health equality issues much earlier than I did. And when I look at how late I started, [noticing these inequalities] I think: yes, there are some people who [noticed them] earlier. But the crazy thing is these people are not activists" - participant 4.

Similarly, experiences or comments during their work as a physician contributed to their awareness of health equality issues. "A sexologist opened my eyes with the following question: When a woman comes to you with a sterilization request, do you also ask her why she has to be sterilized and not her spouse?"-participant 2.

The participants in general said that medical training pays too little attention to the development and awareness of health inequalities: "That should be more in the training to develop ... that [awareness] in people who do not have it and make it stronger in people who do have it."-participant 6. Participants mentioned several topics that were covered insufficiently in their education and training but that could help to develop physicians' awareness of health inequalities, such as discussing ethical dilemmas, developing empathy, discussing the responsibilities of a physician, conversations about human rights, and exploring which 
values underlie medicine. "The norms and values from which we practice medicine have hardly been discussed"-participant 7.

\subsection{Moral Discomfort}

Our definition posits that moral discomfort is a psychological state of unease, which results from becoming aware of a situation or problem that is not in accordance with one's moral values and feeling the responsibility to do something about it. The participants mentioned awareness of social, economic, and societal inequalities and problems in healthcare as an important first step and motivator for activism, but they also noted that many physicians who are aware of certain problems do not immediately take action. A group of people with a certain amount of moral discomfort may choose to accept a problem or not perceive the problem as sufficiently important to act: "I think you are forgetting a very large group [... ] who think if we don't see it, then we don't have to think about it"-participant 5. On the other hand, the participants indicated that the choice for medicine and for a particular specialty often originated from a reaction to a certain moral discomfort, and indicated that, for many physicians, a reason for choosing their training could have been the need to link this moral discomfort to an action.

\subsection{Action within the System}

According to the participants, many physicians derive sufficient satisfaction from the action of 'dedicating oneself daily to patient care' within the system to manage their moral discomfort. These physicians obtain enough satisfaction from acting within a healthcare system to balance this moral discomfort and give purpose to their professional life. "There are many different ways in which people can contribute. Maybe all physicians do that already by becoming physicians"-participant 3.

Moral discomfort may be followed by dedicated actions that are accepted by the system and that are important for continuous improvement within a feedback cycle of the system. However, one of the participants mentioned that there are also physicians with moral discomfort who do not immediately know how to convert this discomfort into an appropriate action. "How many colleagues come to me for a cup of coffee because they want to do something else, who are dissatisfied but cannot even think of what they want, or do not dare to say it or cannot say it"-participant 5 .

Several participants mentioned that they started to act within the system and had conversations with peers about the issues they were concerned about. They also reported having helped individual patients, but there were many factors that prevented them from achieving their goals on the issues they were committed to: "Within the system, the cycle doesn't change. How I see it now, is that you're in the consulting room with a patient who has lung cancer. At the same time, you see that his children are already smoking. There are 3.5 million smokers in the Netherlands. And you also see that his grandchildren are also starting, because [in the Netherlands] 70 children a day start smoking. So, the consulting room keeps filling up" -participant 4.

The participants said that they eventually decided to step outside the system to bring about change when they noticed that actions within the system did not produce sufficient results or satisfaction to reduce the moral discomfort that they felt.

\subsection{Resistance from within the System}

For several participants, the first resistance that they encountered was the disbelief of immediate colleagues, who told them that the problem was too big to change, so that their efforts would have no effect or that it was not their job as physicians to tackle these problems. "You just have to treat illnesses and that's important. And the rest is for other people" -participant 4.

The participants noted that resistance from within the system could also result in a trade-off between personal priorities and their moral discomfort, which usually caused the moral discomfort to be overridden by personal interests. The participants experienced 
personal consequences, such as feeling isolated, having to sign a contract of silence, having labor disputes, and even being suspended, or finally falling ill as a result. One specialist trainee was severely criticized and received a failing grade during her residency on her role of health advocate because of her activist expressions: "I received a failing grade from my supervisor for my role as a health advocate. My supervisor felt that I acted completely wrong and he really did give me a failing grade" - participant 1 . At the time of the interview, one of the participants was suspended from her work as a physician due to her activism: "You can also destroy yourself while fighting against the system, and many people have done that. Choosing your battles is very important. You can't address everything. I have seen people who fought against the system and then got thrown out. They are done, they are exhausted, they don't win, they keep running into more barriers, people get more and more frustrated. We don't see them in the media, because they disappear, or we have seen them for [only] a while because they disappear, but they are out there, and I know some people who have done that [fought against the system and got thrown out], and it is very sad"-participant 3.

The types of activism the participants used varied from creating an activism group addressing the injustice of the status quo, lobbying politicians around such a subject, giving disputed interviews in the Dutch media and creating media attention for a specific controversial problem, attending and organizing protests and demonstrations or secret meetings, starting lawsuits against the state or, very practically, smuggling abortion pills.

\subsection{Turning into an Activist}

The participants described leadership qualities as one of the important skills a physician-activist must possess to change the status quo: "A health activist is someone who makes an above-average effort to make problems visible in society and health care which a physician can change through their medical expertise, and who tries to change and build coalitions" - participant 5; "You can only be an activist if you are a bit of a leader, because you have to be at the very forefront of the troops"-participant 7.

The participants reported that health activists feel forced to step outside the system because of the resistance in the system when they address an issue that they feel the responsibility to do something about (i.e., moral discomfort). "The difference between someone who stands up and the average physician is that the average physician does not fight the system but provides the patient with the best possible service. And the one who stands up has the guts to overturn or change a system if the system does not act in favor of the patient." "We do it for the patient, not for the physician and not for the nurse, not for the director and not for the manager"-participant 5.

While feeling forced to step outside the system and fighting it, the activists' goal is in fact to make an important point and remain accepted by that same system. "I try to stay close to the system, even though I am an oddity. I have a lot of contact with [name of an organization]. I want the connections. I always want to make sure that everyone comes together, and that the network gets bigger and stronger"-participant 4. "I think a lot about to what extent I want to be an activist, because I do want to be effective. And I think I am effective as an activist, by taking the frontrunners with me or being part of the frontrunners instead of standing outside the group and shouting very loudly"-participant 7.

Participants indicated that there are limits to health activism and that they find it important to avoid any violence or material damage. "I still think people who cut petrol hoses are different people and they do different things than I do"-participant 4.

\subsection{Achieving Success as an Activist}

The participants regarded activism as successful if it causes a system to change in such a way that resistance disappears and the formerly activist goal is accepted. According to the participants, this change may happen if they navigate on the edge of the system, sometimes networking within the system and sometimes clearly making their voices heard outside the system, without getting too far removed from it and losing contact. 
Activists who lose contact with the system are more likely to experience personal disadvantages and negative consequences and are more likely to fail in achieving their goals: "This is real career damage. I'm pulled out of everything. I've been amputated. My team, my university, all my schooling. I've been at home for two months"-participant 6.

Activists who navigate on the edges of the system and build a network of contacts inside the system are more likely to receive support and appreciation. "But I think I encounter so little resistance or relatively little resistance because at the same time I also experience that there is appreciation for [my activism]. That does make it easy to keep going"-participant 4.

The various attributes that a health activist must possess in order to achieve success in reaching their predetermined goal were not mentioned during the medical training of any of the participants, nor in their continued professional development. However, the participants realized that, after working as a physician and failing to change serious issues in the provision of healthcare or in the prevention of disease from within the system, they needed to step outside the system to address these issues. Almost all participants took risky steps at the beginning of their activism, such as engaging on national media without media training or having arguments with their supervisors, which moved them relatively far away from the system. By learning specific skills in the areas of communication, leadership, networking, media appearance, and persistence, the effective activists were able to regain contact with the system and meander along its borders. This suggests that it is possible to learn these different skills that are required to successfully change the system and avoid personal disadvantages as a health activist: "You can teach facets of leadership to any person"-participant 5.

\section{Discussion}

To gain a better understanding of health activism, we aimed to gather the views and experiences of health activists in the Dutch health system. This is part of our exploration of whether the current health system, which is in a state of transition, could benefit from some activism. Therefore, as a first step, we asked activists why they were engaged in health activism and what effective strategies looked like. The results show that when physicians become aware of injustice, they feel morally discomforted and feel the responsibility to act. Some find ways to neutralize this feeling is by working within the current system. Others with certain traits, such as a strong drive to speak up despite personal risks, persist in pursuing their goals and potentially become activists when the system they want to change offers resistance. Successful activists describe a strategy of meandering along the borders of the system, countering injustice from outside the system while cherishing contacts with supporters and coalitions with equal-minded professionals within the system.

We observed that activism is about action that challenges or upsets the status quo and does no longer fit within the job description. In our research, the goal of physician activism is always related to changing policies. Possibly, this should be included in the literature's definition of activism.

\subsection{Influence of Activists}

Stakeholder action is part of the mechanism linking corporate social performance and financial performance [22]. How companies respond to action depends, among other things, on the influence of the stakeholder, the type of stakeholder, and which role the stakeholder has in the company [22,23].

Our finding that awareness of injustice or witnessed injustices motivated activism in our participants is in line with a study about motives and antecedents in nursing activism [32]. Because the reaction of a system depends on the influence of the activist stakeholder, the type of stakeholder, and which role the stakeholder has in the company [22,23]. Follow-up research may reveal whether activism by different stakeholders within the healthcare system leads to different reactions of the healthcare system. Another topic for future research is how directors and managers may constructively deal with activism to 
change the system in a way that is more in line with the requirements of a sustainable approach to healthcare.

\subsection{Education}

Stakeholder activism depends on the stakeholders' awareness of the company's inadequate policies, on whether they are willing to take action, and on whether they have the capacity to speak to those in power [14,22]. In our research, the actions of physicianactivists depended on similar factors. Physician-activists indicated that medical education did not make them aware of socio-economic injustice and had not taught them to express themselves in an activistic way.

In our research, the participants did not recall a specific moment that motivated their activism, but that they became activists through a process of motivation and empowerment. This process, in which the participants became aware of injustice, felt morally discomforted, and started questioning the system and eventually took action, shows a great similarity with the socialist concept developed by the Brazilian pedagogue and educational theorist Paulo Freire, which was grounded in Marxist critical theory. Paulo Freire named this process 'conscientização', which is translated as critical consciousness [33], the process of empowerment [34] in which individuals "learn to perceive social, political and economic contradictions" to reflect on their own feelings and to take action against systems of oppression or injustice [33].

There is great overlap between the process from awareness to activism in our research and the development of critical consciousness. In developmental psychology, critical consciousness is divided into "critical reflection, political efficacy and critical action/praxis" [35]. Critical reflection is a process of "identifying, questioning, and assessing our deeply-held assumptions about our knowledge and the way we perceive events and issues, our beliefs, feelings, and actions" [36]. In our study, critical reflection overlapped with the awareness of injustice, which, for several participants, resulted from experiences in foreign countries. In political science, political efficacy is "the feeling that individual political action does have, or can have, an impact upon the political process" [37]. Even after disbelief among colleagues and resistance from the system, all participants felt that they could impact the political process. Critical action or praxis is action directed at systems in order to transform them [33], in our study described as activism.

Besides the large overlap between our study and critical consciousness theory, the process we found seems more detailed. In our study, activists first tried to carry out actions within the system, before stepping outside the system. In critical consciousness theory, action within and outside the system is less clearly discussed. The steps in the process found in our study may be more suitable to base education on, because you want to give people all the tools they need to first find a solution within a system, but also the awareness that some things cannot be solved within a system.

Our research shows that a successful activist is created by a courage to speak up despite personal risks and by the development of critical consciousness. For successful activism, appropriate skills and competences are necessary.

In medical education, much attention has been paid in recent years to the development of competences and roles. Our study suggests that communication, leadership development, and networking are important competences for successful activism.

All the participants mentioned that medical training pays too little attention to raising awareness of health inequalities and on how to take action against the causes of these inequalities. In behavioral and social science in particular, but also in medicine, research has been done on the ways of teaching critical consciousness and applying it in education [34-37].

Looking at the skills that are necessary for successful activism and the overlap between critical consciousness and the process from awareness to activism in our research, the idea emerges that activism itself, from initial awareness up to successful activist initiatives, may be regarded as a series of social and professional skills that can be learned. 
As stakeholders, doctors may have an influential role in shaping and changing the healthcare system, but due to a lack of training in activistic capacities and in awareness of social injustice, it is suspected that few physicians who might be willing to take action even know that they have the capacity to speak to those in power or feel skilled enough to do so. This situation is also perpetuated by the current view of activism in medical education.

Educating physicians may help. According to Wheeler-Bell [38], the ideal society can be created by teaching "the spirit of activism-a sense of justice that becomes part of the person's salient social identity". The author points out that civic education should be critical, "which means providing students with the skills and abilities to transform society". This education should prepare students to participate in society, make them aware of social problems and teach them to think critically. Such a plea is in line with the demands of the healthcare system of the 21st century, for which medical training should nurture agents of change [7].

In literature, there is a lot of overlap between activism and leadership [39-42], and the participants in our research mentioned that one also needs to have leadership qualities to be an activist. Despite having different views on medical leadership, physicians agree that important factors in leadership are personal skills in collaboration and communication, having integrity, and having a clear vision [39]. In our research, the participants needed these same skills to be successful, which makes successful activism a good example of medical leadership.

An important next step is investigating the success factors of reformative activism in healthcare [14], and how to incorporate reformative activism and critical consciousness [33-35] in medical educational programs.

\subsection{Institutional/System Change}

According to the theory of institutional change, institutions or systems change after they have been sufficiently destabilized and then reinstitutionalized with new views. This change is the ultimate goal of an activist [14].

There are two different types of activists: reformative activists and radical activists. Reformative activists believe that the organization they are campaigning against can also be part of the solution, while radical activists believe that this organization cannot be part of the solution. [14] In our research, the physician-activists felt forced to step outside the system to act, but their goal was to be accepted by the same system they were countering and, in that way, to effectuate system change. It is striking that the most important success factors that the participants in our study mentioned were networking and staying in contact with the system they were trying to change. This cooperative attitude indicates that all the participants included in our research were reformative activists, for whom activism is not about extremes. An item for future research is whether radical activism is an option at all for physicians.

\subsection{Strengths and Limitations}

Successful reformative activism is linked to a final acceptance of the proposed change by the system, and the activists in our study made a plea for keeping connections with the system at all times. Unsuccessful and radical activists, on the other hand, lost contact with the system and soon became less visible. Therefore, they constitute a group to which we had less access, because they are not visible in the media and we did not find them with the snowballing technique we applied. With the snowballing technique, we reached saturation on our questions early in our research, despite having a limited number of interviews. A possible limitation of this is the introduction of homogeneity in our participants, which may explain the early saturation. It would be interesting to speak to more unsuccessful and radical activists to find out what can be learned from their experiences and to examine whether there is an unknown heterogeneity. A strong factor of this research is that we used thematic analysis inspired by the grounded theory that enabled us to get a picture of the drop out race in becoming an activist. In our research, it was difficult to find good examples 
of physician health activists in the Dutch healthcare system. There were no interviews conducted with physicians that did not participate in health activism, which is a limitation of this research and can be of importance for further research in reasons why physicians do not participate in health activism.

\section{Conclusions}

In all participants, awareness, moral discomfort, and resistance from within the system were factors that stimulated their activism. Taking an activistic role may damage one's career, but some physicians have a strong altruistic drive to fight injustice, which overrules their fear of consequences. Our research suggests that activism originates from a strong drive to speak up against perceived injustice, despite the personal risks involved. Possible factors that prevent physicians from expressing themselves in an activist way are resistance from within the system and a lack of education aimed at the awareness of inequality and successful activism.

The participants regarded activism as successful if it causes a system to change in such a way that resistance disappears and the formerly activist goal is accepted. According to the participants, the most prominent feature of a successful and effective health activism strategy is navigating on the edge of the system, sometimes networking within the system and sometimes clearly making your voice heard outside the system, without getting too far removed from it and losing contact. Activists who build a network of contacts inside the system are more likely to receive support and appreciation.

The various attributes that a health activist must possess in order to achieve success were not mentioned during the medical training of any of the participants, nor in their continued professional development. By learning specific skills in the areas of communication, leadership, networking, media appearance and persistence, the effective activists were able to regain contact with the system and meandered along its borders. Our research suggests that the process of successful activism may be learned by focusing not only on knowledge and on the improvement of these particular skills, but also on the learners' in-depth understanding and awareness of socio-economic and political challenges. For sustainable development, the health system could benefit from some activism. The role of medical education in developing critical doctors, agents of change, and possibly even activists, needs to be further explored.

Author Contributions: Conceptualization, E.H., F.S., G.K. and G.L.; methodology, E.H. and F.S.; software, E.H.; validation, E.H. and F.S.; formal analysis, E.H.; investigation, E.H.; resources, F.S.; data curation, E.H., F.S., G.K. and G.L.; writing-original draft preparation, E.H. and F.S.; writing-review and editing, E.H., F.S., G.K. and G.L.; visualization, E.H. and F.S.; supervision, F.S.; project administration, E.H. All authors have read and agreed to the published version of the manuscript.

Funding: This research received no external funding.

Institutional Review Board Statement: All subjects gave their informed consent for inclusion before they participated in the stud. The study was conducted in accordance with the Declaration of Helsinki, and the protocol was approved by the Institutional Review Board of OLVG Hospital (ACWO 21u.1 /MJ/WO 21.149).

Informed Consent Statement: Informed consent was obtained from all subjects involved in the study.

Data Availability Statement: Data is not publicly available, though the data may be made available on request by the corresponding author.

Conflicts of Interest: The authors declare to have no conflict of interest. 


\section{References}

1. $\quad$ Essink, D.R.; Spanjers, R.R.; Broerse, J.E.W.; de Cock Buning, J.T. Sustainable development: A guiding vision in health system innovation? In Transitions in Health Systems: Dealing with Persistent Problems; Broerse, J.E.W., Bunders, J.F.G., Eds.; VU University: Amsterdam, The Netherlands, 2010; pp. 87-112.

2. The Millennium Development Goals Report 2015; United Nations: New York, NY, USA, 2015.

3. Morton, S.; Pencheon, D.; Squires, N. Sustainable Development Goals (SDGs), and their implementation. Br. Med. Bull. 2017, 124, 81-90. [CrossRef]

4. Morton, S.; Pencheon, D.; Bickler, G. The sustainable development goals provide an important framework for addressing dangerous climate change and achieving wider public health benefits. Public Health 2019, 174, 65-68. [CrossRef] [PubMed]

5. Weinberger, K.; Rankine, H.; Amanuma, N.; Surendra, L.; Van Hull, H.V.; Foran, T.; Reyes, R.; Malik, A.; Murray, J. Integrating the Three Dimensions of Sustainable Development: A Framework and Tools; United Nations, ESCAP (Environmental and Social Commission for Asia and the Pacific): Bangkok, Thailand, 2015.

6. Scott, M.D.; McQueen, S.; Richardson, L. Teaching Health Advocacy: A Systematic Review of Educational Interventions for Postgraduate Medical Trainees. Acad. Med. 2020, 95, 644-656. [CrossRef] [PubMed]

7. Frenk, J.; Chen, L.; Bhutta, Z.A.; Cohen, J.; Crisp, N.; Evans, T.; Fineberg, H.; Garcia, P.; Ke, Y.; Kelley, P.; et al. Health professionals for a new century: Transforming education to strengthen health systems in an interdependent world. Lancet 2010, 376, 1923-1958. [CrossRef]

8. Bunders-Aelen, J.G.F.; Broerse, J.E.W. The Urgency for Change. In Transitions in Health Systems: Dealing with Persistent Problems; Broerse, J.E.W., Bunders, J.F.G., Eds.; VU University Press: Amsterdam, The Netherlands, 2010; pp. 1-18.

9. Grol, R.; Wensing, M. Implementation of change in healthcare: A complex problem. In Improving Patient Care. The Implementation of Change in Health Care; Wiley-Blackwell: Hoboken, NJ, USA, 2020; Chapter 1.

10. Buse, K.; Hawkes, S. Health in the sustainable development goals: Ready for a paradigm shift? Glob. Health 2015, 11, 1-8. [CrossRef] [PubMed]

11. Laverack, G. Health activism: The way forward to improve health in difficult times. Glob. Health Promot. 2013, $20,49-52$. [CrossRef] [PubMed]

12. Cambridge Dictionary. Available online: https://dictionary.cambridge.org/dictionary/english/activism (accessed on 12 April 2021).

13. Martin, B. Activism, social and political'. In Encyclopedia of Sociology, 2nd ed.; Andersen, G.L., Herr, K.G., Eds.; Macmillan: New York, NY, USA, 2007; pp. 2727-2735.

14. Hond, F.D.; de Bakker, F. Ideologically motivated activism: How activist groups influence corporate social change activities. Acad. Manag. Rev. 2007, 32, 901-924. [CrossRef]

15. Sessums, L.; Dennis, L.; Liebow, M.; Moran, W.; Rich, E. (Eds.) Health Care Advocacy: A Guide for Busy Clinicians; Springer Science \& Business Media Springer-Verlag: New York, NY, USA, 2011.

16. Zoller, H.M. Health Activism Targeting Corporations: A Critical Health Communication Perspective. Health Commun. 2016, 32, 219-229. [CrossRef]

17. Labonté, R. Health activism in a globalising era: Lessons past for efforts future. Lancet 2013, 381, 2158-2159. [CrossRef]

18. Brown, T.M.; Fee, E. Social Movements in Health. Annu. Rev. Public Health 2014, 35, 385-398. [CrossRef]

19. Berridge, V. Public health activism: Lessons from history? BMJ 2007, 335, 1310-1312. [CrossRef]

20. Wright, J. Only Your Calamity: The Beginnings of Activism by and for People with AIDS. Am. J. Public Health 2013, 103, 1788-1798. [CrossRef]

21. France, D. How to Survive a Plague: The Story of How Activists and Scientists Tamed AIDS; Pan Macmillan: Hampshire, UK, 2016.

22. Rowley, T.; Berman, S. A BrandNew Brand of Corporate Social Performance. Bus. Soc. 2000, 39, 397-418. [CrossRef]

23. Rodriguez-Fernandez, M. Social responsibility and financial performance: The role of good corporate governance. $B R Q B u s$. Res. Q. 2016, 19, 137-151. [CrossRef]

24. Ricketts, A. The Activists' Handbook: A Step-by-Step Guide to Participatory Democracy; Zed Books Ltd., Bloomsbury Publishing Plc: London, UK, 2012.

25. Takahashi, S.G. (Ed.) CanMEDS Teaching and Assessment Tools Guide; Royal College of Physicians and Surgeons of Canada: Ottawa, ON, Canada, 2015.

26. Hubinette, M.M.; Ajjawi, R.; Dharamsi, S. Family Physician Preceptors' Conceptualizations of Health Advocacy. Acad. Med. 2014, 89, 1502-1509. [CrossRef] [PubMed]

27. Dobson, J. Youth activism for health: Taking the future into their own hands. BMJ 2019, 367, 16881. [CrossRef] [PubMed]

28. Patton, M.Q. Qualitative research. In Encyclopedia of Statistics in Behavioral Science; SAGE Publications Inc: Thousand Oaks, CA, USA, 2005.

29. Green, J.; Thorogood, N. Qualitative Methods for Health Research; Sage: London, UK, 2018.

30. Saunders, B.; Sim, J.; Kingstone, T.; Baker, S.; Waterfield, J.; Bartlam, B.; Burroughs, H.; Jinks, C. Saturation in qualitative research: Exploring its conceptualization and operationalization. Qual. Quant. 2017, 52, 1893-1907. [CrossRef]

31. Jootun, D.; McGhee, G.; Marland, G.R. Reflexivity: Promoting rigour in qualitative research. Nurs. Stand. 2009, 23 , 42-46. [CrossRef] [PubMed]

32. Florell, M.C. Concept analysis of nursing activism. Nurs. Forum 2020, 56, 134-140. [CrossRef] 
33. Freire, P. Pedagogy of the Oppressed; The Continuum International Publishing Group Inc.: New York, NY, USA, 2005.

34. Manca, A.; Gormley, G.J.; Johnston, J.L.; Hart, N.D. Honoring Medicine's Social Contract. Acad. Med. 2020, 95, 958-967. [CrossRef] [PubMed]

35. Seider, S.; Clark, S.; Graves, D. The Development of Critical Consciousness and its Relation to Academic Achievement in Adolescents of Color. Child Dev. 2018, 91, e451-e474. [CrossRef]

36. Smith, E. Teaching critical reflection. Teach. High. Educ. 2011, 16, 211-223. [CrossRef]

37. Craig, S.C.; Maggiotto, M.A. Measuring Political Efficacy. Political Methodol. 1982, 8, 85-109.

38. Wheeler-Bell, Q. Educating the Spirit of Activism: A “Critical" Civic Education. Educ. Policy 2012, 28, 463-486. [CrossRef]

39. Van De Riet, M.C.P.; Berghout, M.A.; Buljac-Samardžić, M.; van Exel, J.; Hilders, C.G.J.M. What makes an ideal hospital-based medical leader? Three views of healthcare professionals and managers: A case study. PLoS ONE 2019, 14, e0218095. [CrossRef]

40. Martin, G.L.; Williams, B.M.; Green, B.; Smith, M.J. Reframing Activism as Leadership. New Dir. Stud. Leadersh. 2019, 2019 , 9-24. [CrossRef]

41. Voogt, J.J.; van Rensen, E.; Noordegraaf, M.; Schneider, M.M. Medisch leiderschap ontrafeld [Unravelling medical leadership]. Ned Tijdschr Geneeskd 2015, 159, A9123P.

42. Sadowski, B.; Cantrell, S.; Barelski, A.; O’Malley, P.G.; Hartzell, J.D. Leadership Training in Graduate Medical Education: A Systematic Review. J. Grad. Med. Educ. 2018, 10, 134-148. [CrossRef] [PubMed] 